\title{
Involvement of brain-derived neurotrophic factor in the regulation of hypothalamic somatostatin in vivo
}

\author{
Laurent Givalois, Gaëlle Naert, Lucia Tapia-Arancibia \\ and Sandor Arancibia \\ Molecular Mechanisms in Neurodegenerative Dementia Laboratory, U710 Inserm, University of Montpellier 2, EPHE, Place E Bataillon, \\ 34095 Montpellier, France \\ (Requests for offprints should be addressed to L Givalois; Email: Igivalois@univ-montp2.fr)
}

\begin{abstract}
Brain-derived neurotrophic factor (BDNF) has been extensively studied in the central nervous system as a survival and differentiation factor and in plasticity processes. In vitro, BDNF has been shown to stimulate cellular differentiation and neurohormones synthesis and release. We demonstrated that BDNF is a potent and specific stimulatory agent of somatostatin (SRIH) synthesis in primary cultures of hypothalamic neurons. However, less information is available about its function on SRIH neurons in vivo. In the present study, we examined the effect of in vivo intracerebroventricular BDNF administration in adult non-anesthetized male rats. Two distinct experimental approaches were used: acute intracerebroventricular injection and long-term (14 days) continuous infusion (Alzet micro-pumps). We demonstrate that single intracerebroventricular BDNF injections $(5 \mu \mathrm{g} / \mathrm{rat})$
\end{abstract}

induce an early (60 and $180 \mathrm{~min}$ ) decrease in the SRIH mRNA signal in the hypothalamic periventricular nucleus (PeVN) accompanied by a decrease of the hypothalamic SRIH content. $48 \mathrm{~h}$ after the acute injection, SRIH mRNA levels and peptide content strongly and significantly increased. After continuous intracerebroventricular BDNF administration (12 $\mu \mathrm{g} /$ day for 14 days), a significant increase in the SRIH hypothalamic content was observed. Nevertheless, the increase in peptide content was not correlated with a similar increase in the PeVN messenger level. These findings show the involvement of BDNF in the in vivo regulation of somatostatinergic neurons in adult rats, which clearly differs according to the BDNF administration mode.

Journal of Endocrinology (2006) 188, 425-433

\section{Introduction}

The brain-derived neurotrophic factor (BDNF) is a member of the neurotrophin family having the nerve growth factor as prototype. The main biological effects of BDNF are mediated by specific tyrosine kinase (TrkB) receptors. In adult rats, BDNF is involved in a variety of forms of synaptic plasticity in the central nervous system (CNS). Among these actions, particular interest has been focused on its stimulatory effect on peptide biosynthesis in the CNS (Tapia-Arancibia et al. 2004). BDNF has thus been shown to increase mRNA and peptide levels of neuropeptide $\mathrm{Y}$ and somatostatin (SRIH) in cultured cortical (Nawa et al. 1993) and striatal (Mizuno et al. 1994) neurons. In BDNFknockout mice, the density of SRIH cells is drastically reduced in hippocampus and cortex (Große et al. 2005). In hypothalamic cultures, BDNF has been reported to have a stimulatory effect on SRIH content and mRNA expression (Rage et al. 1999) and on differentiation (Loudes et al. 1999).
In addition, the fact that both SRIH (Benyassi et al. 1993a,b) and BDNF (Rage et al. 2002, Givalois et al. 2004) are molecules involved in the stress response and in food intake regulation (Feifel \& Vaccarino 1994, Pelleymounter et al. 1995) is an important clue in suggesting a functional relationship between these signals. Some of these changes occur in the periventricular nucleus $(\mathrm{PeVN})$, which is a hypothalamic region where BDNF and TrkB mRNAs (Marmigère et al. 1998) and most neuronal perikarya secreting SRIH are localized (Makara et al. 1983).

This data strongly suggests that BDNF might be a signal involved in the control of SRIH in vivo. We assessed this possibility by administering a single BDNF i.c.v. injection in adult rats and analyzing SRIH mRNA levels in the PeVN, the main source of SRIH in the hypothalamus (Brownstein et al. 1975). To compare this treatment with the effects obtained by long-term BDNF infusion, similar studies were also carried out on animals bearing osmotic pumps (Alzet) chronically implanted in the lateral ventricle, which allowsdelivery of a sustained and constant amount of BDNF into the brain. 


\section{Materials and Methods}

\section{Animals}

Adult male Sprague-Dawley rats (Depré, St Doulchard, France) weighing 260-280 g were housed for 1 week under constant temperature $\left(21 \pm 1{ }^{\circ} \mathrm{C}\right)$ and lighting (light on from 07:00 to 19:00) regimens. Food pellets and water were freely available. Procedures involving animals and their care were conducted in compliance with French laws on laboratory animals that, in turn, are in compliance with international laws and policies (EEC Council Directive 86/609, OJ L 358, 1, 12 December 1987, NIH Guide for the Care and Use of Laboratory Animals, NIH Publication No. 85-23 1985). All protocols were approved by the Animal Welfare Committee at the University of Montpellier II, which aims to minimize the number of animals used, and potential pain and distress.

\section{Experimental procedures}

As repeatedly reported (Lapchak \& Hefti 1992, Pelleymounter et al. 1995, Siuciak et al. 1996), we infused BDNF in the lateral ventricle to enable BDNF access to a wide range of periventricular regions, including direct albeit limited access to forebrain areas such as the hippocampus and hypothalamus (Yan et al. 1994, Anderson et al. 1995). This mode of administration produces minimal lesion damage. At the end of each experiment, the correct cannula implantation and tissue integrity was checked, and rats with the wrong cannula localization or presenting lesions were not included in this study. The choice of sodium chloride as vehicle was based on a study of Callahan et al. (2001) showing that the utilization of $\mathrm{NaCl}$ enhanced the shelf-life and conformational stability of BDNF.

\section{Surgery}

Single i.c.v. injection As previously reported for i.c.v. injection studies (Givalois et al. 2004), 7 days before the experiments, the animals were deeply anesthetized with an intramuscular injection of $0.2 \mathrm{ml}$ of a mixture of ketamine hydrochloride $(80 \mathrm{mg} / \mathrm{kg}$ body weight (b.w.)) and xylazine $(10 \mathrm{mg} / \mathrm{kg}$ b.w.). They were then stereotaxically implanted with a permanent stainless-steel cannula (PlasticOne Products Co., Roanoke, VA, USA) into the left lateral ventricle of the brain at coordinates (AP: $-1 \mathrm{~mm}, \mathrm{~L}: \pm 1.5 \mathrm{~mm}$ and $\mathrm{DV}:-3.5 \mathrm{~mm}$ ) according to Paxinos and Watson (1997). The rats were caged separately, handled every day before the experiments and had recovered their preoperative body weight prior to i.c.v. injection. On the day of the experiment, freely moving animals were divided into three experimental groups, i.e. control rats (with no cannula), sham rats that received a single i.c.v. injection of saline $(5 \mu \mathrm{l}$ of $0.9 \% \mathrm{NaCl})$, and treated rats that received a single i.c.v. injection of recombinant human BDNF $(5 \mu \mathrm{g} / \mathrm{rat}$ in $5 \mu \mathrm{l}$ of $\mathrm{NaCl}$ $0.9 \%$; kindly provided by Regeneron Pharmaceuticals Inc., Tarrytown, NY, USA). The BDNF dose was selected on the basis of previous experiments, wherein adequate diffusion of this molecule from lateral ventricle to the periventricular areas was considered (Yan et al. 1994). The effects of i.c.v. injection on the different parameters studied were determined before $\left(\mathrm{t}_{0}\right)$ and 30 , 60, 180, $300 \mathrm{~min}$ and $48 \mathrm{~h}$ after injection.

Continuous i.c.v. injection The animals were also divided in three groups: control, sham and treated. The control group was composed of intact untreated rats, whereas sham and treated rats had an osmotic pump (Alzet model 2002, $200 \mu \mathrm{l} ; 0.5 \mu \mathrm{l} / \mathrm{h}$; Charles River, France) implanted in the lateral ventricle, as previously reported (Pelleymounter et al. 1995). Before surgery, each rat was intra-muscularly anaesthetized with a ketamine $(80 \mathrm{mg} / \mathrm{kg}$ b.w.) and xylazine $(10 \mathrm{mg} / \mathrm{kg}$ b.w.) mixture. For the osmotic pump implantation, each animal was placed on the stereotaxic apparatus to implant a cannula into the left lateral ventricle, as detailed above. The cannula was sealed with dental cement and connected to an Alzet pump by medical grade vinyl tubing. The pump was placed into a subcutaneous pocket in the dorsal region. For the sham group, the pumps were filled with vehicle $(\mathrm{NaCl} 0.9 \%)$ and for the treated group with a BDNF solution $(1 \mu \mathrm{g} / \mu \mathrm{l}$; kindly provided by Regeneron Pharmaceuticals Inc.). Animals implanted with osmotic pump filled with BDNF received $12 \mu \mathrm{g}$ /day of BDNF for 14 days. The pumps were filled the day before surgery was performed. The pumps and the tubing were incubated at $37^{\circ} \mathrm{C}$ overnight in a sterile saline solution to prime them. The experiment continued for 14 days after pump implantation. The BDNF dose was selected on the basis of previous experiments (Siuciak et al. 1996) and this protocol was validated by the loss of body weight observed in treated animals (Lapchak \& Hefti 1992, Pelleymounter et al. 1995, Siuciak et al. 1996), which indicates a BDNF access to the hypothalamic areas.

\section{Preparation of digoxigenin-labeled oligonucleotide probe}

As previously reported (Arancibia et al. 2001), a 45-mer oligonucleotide antisense probe for somatostatin-14 (5' to $3^{\prime}$ sequence: CCAGAAGAAAGTTCTTGCAGCCAGCTTTGCGTTCCCGGGGTGT) (Genosys, Cambridge, UK) was end-labeled with digoxigenin-11-dideoxyuridine- $5^{\prime}$-triphosphate. Negative controls were carried out by omitting the labeled probe from the hybridization buffer, or by incubating the sections with a 45-base oligonucleotide sense probe based on the somatostatin-14 sequence. Labeling was carried out according to the same protocol as described for the antisense probe, same concentration as the antisense probe were used. 
In situ hybridization

On the day of the experiments, the animals were deeply anesthetized with an intramuscular injection of $0.2 \mathrm{ml}$ of a mixture of ketamine hydrochloride $(80 \mathrm{mg} / \mathrm{kg} \mathrm{b.w.)}$ and xylazine $(10 \mathrm{mg} / \mathrm{kg} \mathrm{b.w.)}$ and then rapidly perfused transcardially with $4 \%$ paraformaldehyde in $0.2 \mathrm{M}$ phosphate buffer. Brains were removed and postfixed in the same fixative for $4 \mathrm{~h}$ at $4{ }^{\circ} \mathrm{C}$, and then placed in $15 \%$ sucrose overnight at $4{ }^{\circ} \mathrm{C}$. Thereafter, the tissues were quickly frozen in isopentane chilled in liquid nitrogen. The frozen brains were mounted on a cryostat (Leica, RueilMalmaison, France) and serially cut into $10 \mu \mathrm{m}$ coronal sections. The hypothalamic sections were mounted on Superfrost-Plus glass slides (Menzel-Glaser, Labonord, Templemars, France) and kept at $-80{ }^{\circ} \mathrm{C}$ until use.

In situ hybridization analysis was carried out as previously described (Arancibia et al. 2001). Briefly, the paraformaldehyde-fixed sections were washed for $5 \mathrm{~min}$ in PBS before incubation at room temperature for $10 \mathrm{~min}$ with $10 \mathrm{mg} / \mathrm{ml}$ of proteinase $\mathrm{K}$. The sections were then acetylated with $0 \cdot 25 \%$ acetic anhydride for $10 \mathrm{~min}$. They were then dehydrated in an ascending series of ethanol concentrations and air-dried. The sections were hybridized overnight in a humid chamber at $37^{\circ} \mathrm{C}$ with $3 \mathrm{ng}$ of SRIH-labeled probe in $30 \mu \mathrm{l}$ of hybridization mixture. After hybridization, the sections were then rinsed briefly and incubated at room temperature with $2 \%(\mathrm{w} / \mathrm{v})$ blocking reagent: $0 \cdot 1 \%$ diethyl pyrocarbonate for $30 \mathrm{~min}$ to block nonspecific antibody reactions. Slides were then transferred to a humid chamber and incubated with a 1:500 dilution of alkaline phosphatase-conjugated antidigoxigenin antibody (Roche) containing 2\% (w/v) nonfat dry milk for $2 \mathrm{~h}$. This was followed by two 15-min washes before transfer to a color developing solution, containing nitroblue tetrazolium salt and 5-bromo-4chloro-3-indolyl phosphate. The color reaction was stopped after $10 \mathrm{~h}$ by washing in $200 \mathrm{ml}$ of $1 \times$ TrisEDTA buffer, $\mathrm{pH} \mathrm{8}$, for $30 \mathrm{~min}$. Excess Tris buffer was wiped off, and the sections were coverslipped with Entellan (Merck).

\section{Image analysis}

We took advantage of the non-isotopic in situ hybridization technique, which is a valuable method to quantify the results as initially reported from Kiyama and Emson (1990). Thus, the histological sections of the PeVN region were analyzed by counting all labeled cells/section and by measuring the optical density (OD) variations using a Sony CCD XC-77 video camera with high-resolution (570 (H) 3485 (V) TV lines) coupled to a Macintosh computer (Power PC G3) and NIH-Image software (version 1.63 non-FPU, W. Rasband, NIH, Bethesda, MD) (Arancibia et al. 2001, Givalois et al. 2004). For each animal, an OD and a number of positive cells/section from four to six sections measured on each side of the PeVN were determined to calculate a mean per animal. The OD of each specific region was corrected for the average background signal determined by sampling cells immediately outside the cell groups of interest. The experiments were performed twice independently and all sections from control, sham and treated animals were hybridized at the same time to avoid intrinsic variations between different in situ hybridizations.

\section{Hypothalamic SRIH content}

After decapitation, hypothalami were dissected and immediately frozen on dry ice and stored at $-20{ }^{\circ} \mathrm{C}$ until the SRIH assay. SRIH hypothalamic contents were measured with a conventional RIA. The SRIH RIA kit (Phoenix Pharmaceuticals Inc., Belmont, USA) was used according to the manufacturer's protocol. The assay sensitivity was $2 \mathrm{pg} /$ tube. SRIH content was expressed as $\mathrm{pg} /$ hypothalamus. The intra- and inter-assay coefficients of variation were $4 \%$ and $7 \%$, respectively.

\section{Statistical analysis}

Data was presented as mean \pm S.E.M. Mean and S.E.M. were calculated from 5-6 animals per group for SRIH assay and for the in situ hybridization analysis. The different groups were compared by performing an ANOVA (Statview 4.5) followed by a Fisher's PLSD test, as previously reported (Arancibia et al. 2001, Givalois et al. 2004). P<0.05 was considered significant.

\section{Results}

Effect of single i.c.v. BDNF injection on SRIH $m R N A$ and SRIH hypothalamic content

Figure 1 shows time-course variations in SRIH mRNA signals in the PeVN in controls and 60, 180, $300 \mathrm{~min}$ and $48 \mathrm{~h}$ after BDNF injection.

The SRIH mRNA signal was evaluated in the PeVN, the hypothalamic region containing most of somatostatinergic neuron perikarya. Quantifications of messenger variations are represented in Fig. $2 \mathrm{~A}$ and $2 \mathrm{~B}$. BDNF injection rapidly and significantly $\left(\mathrm{F}_{4,18}=146,7 ; P<0 \cdot 0001\right)$ decreased SRIH mRNA signal (OD) 60, 180 and $300 \mathrm{~min}$ after BDNF injection $(-23 \%$ at $60 \mathrm{~min}, P<0 \cdot 01$ versus control $\left(\mathrm{t}_{0}\right) ;-17 \%$ at $180 \mathrm{~min}, \quad P<0 \cdot 01$ versus control $\left(\mathrm{t}_{0}\right)$ and $-20 \%$ at $300 \mathrm{~min}, P<0 \cdot 01$ versus control $\left.\left(t_{0}\right)\right)$. By contrast, at $48 \mathrm{~h} \mathrm{SRIH} \mathrm{messenger} \mathrm{levels} \mathrm{were}$ significantly increased by $20 \%(P<0 \cdot 01$ versus control rat $\left(t_{0}\right)$ ) (Fig. 2A). The number of positive cells expressing SRIH mRNA in the PeVN was significantly decreased $\left(\mathrm{F}_{4,17}=23.02 ; P<0.0001\right) 60$ and $180 \mathrm{~min}$ after BDNF injection $\left(-19 \%\right.$ at $60 \mathrm{~min}, P<0 \cdot 01$ versus control rat $\left(\mathrm{t}_{0}\right)$ 


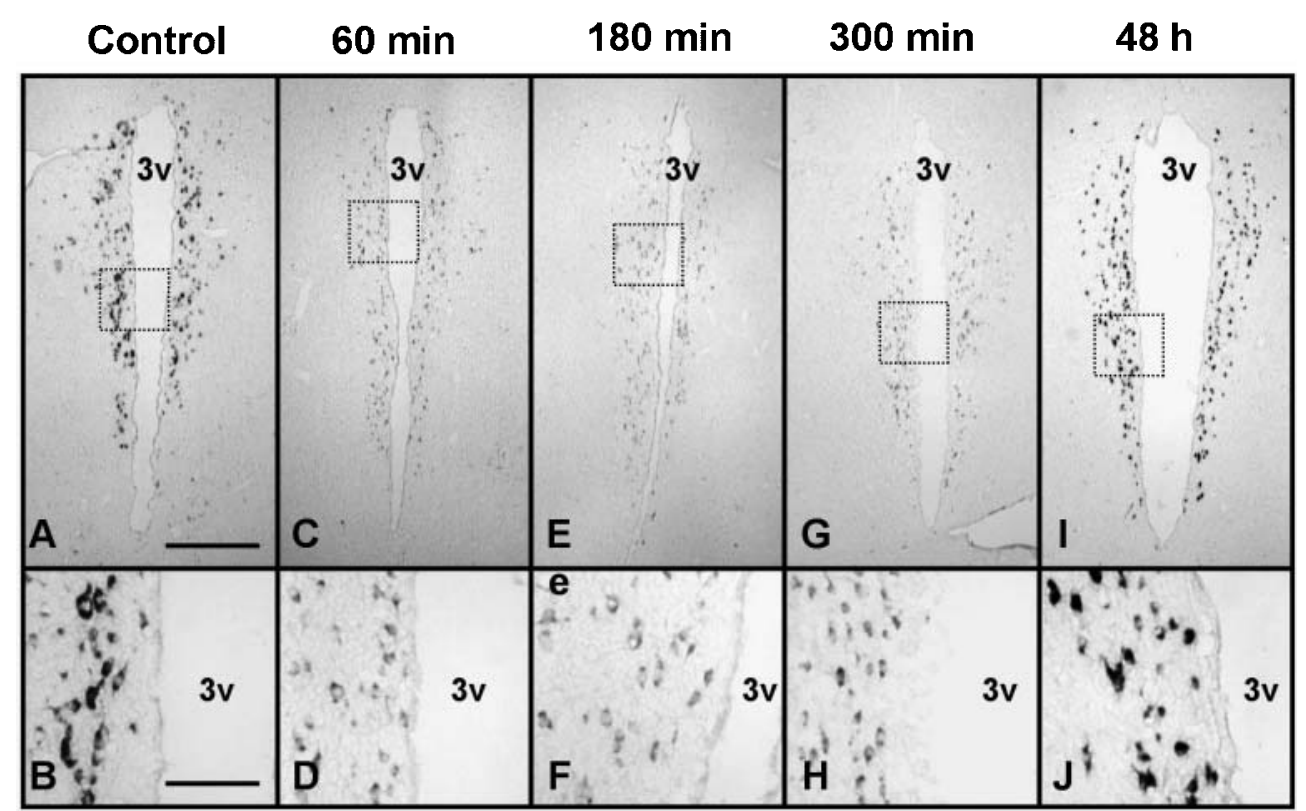

Figure 1 Effects of single i.c.v. BDNF injection ( $5 \mu \mathrm{g} / \mathrm{rat}$ ) on SRIH mRNA expression in the PeVN, detected

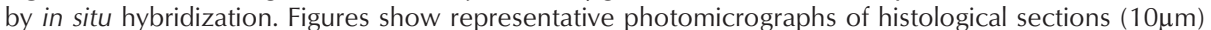
hybridized with digoxigenin-labeled SRIH oligonucleotide probe in control adult male rats (a and b), 60 (c and d), 180 (e and f), $300 \mathrm{~min}$ ( $\mathrm{g}$ and $\mathrm{h}$ ) and $48 \mathrm{~h}$ ( $\mathrm{i}$ and j) after a single i.c.v. injection of BDNF (5 $\mu \mathrm{g} / \mathrm{rat}$ ). Photomicrographs a, c, e, g and i: scale bar $=400 \mu \mathrm{m}$ and photomicrographs b, d, f, h and j: scale bar $=100 \mu \mathrm{m}$. 3v: third ventricle.

and $-12 \%$ at $180 \mathrm{~min}, P<0 \cdot 05$ versus control rat $\left.\left(\mathrm{t}_{0}\right)\right)$. At $300 \mathrm{~min}$, the number of positive cells/section was comparable to the control value and was increased by $15 \%$, $48 \mathrm{~h}$ after the treatment $\left(P<0 \cdot 05\right.$ versus control rat $\left.\left(\mathrm{t}_{0}\right)\right)$ (Fig. 2B). Figure 2C shows time-course variations of hypothalamic SRIH contents in control animals $\left(t_{0}\right)$ and 30, 60, $180 \mathrm{~min}$ and $48 \mathrm{~h}$ after a single BDNF injection. The SRIH content was progressively and significantly decreased $\left(\mathrm{F}_{3,27}=3 \cdot 77 ; P<0 \cdot 022\right) 60$ and $180 \mathrm{~min}$ after BDNF injections $(18.7 \pm 2.7 \mathrm{ng} /$ hypothalamus at $60 \mathrm{~min}$, $P<0.01$ and $23.6 \pm 1.9 \mathrm{ng} /$ hypothalamus at $180 \mathrm{~min}$, $P<0.05$ versus $37.9 \mathrm{ng} /$ hypopthalamus in control rats $\left.\left(\mathrm{t}_{0}\right)\right)$. By contrast, at $48 \mathrm{~h}$ the SRIH content was significantly increased $\left(\mathrm{F}_{1,14}=18.39 ; \mathrm{P}<0.0008\right)$ by $54 \%(56.9 \pm 3.9$ versus $37.9 \pm 3.9$ in control rats $\left.\left(t_{0}\right)\right)$ (Fig. $2 \mathrm{C}$ ).

In situ hybridization of SRIH mRNA as well as SRIH hypothalamic content variations were performed in control, sham and BDNF-treated rats. No difference was observed between control and sham groups. Hybridizations with the sense probes did not reveal any positive signal.

Effect of continuous i.c.v. BDNF administration on SRIH $m R N A$ and SRIH hypothalamic content

Figure 3 shows that, as expected, long-term BDNF treatment (i.c.v. infusion of BDNF, $12 \mu \mathrm{g} /$ days for 14 days) has decreased body weight compared with control and sham rats $\left(\mathrm{F}_{2,10}=17 \cdot 69 ; P<0 \cdot 0005\right)$ indicating $\mathrm{BDNF}$ access to hypothalamic areas as already established (Lapchak \& Hefti 1992). This decrease was significant from 7 days of treatment $(341 \pm 15$ versus $398 \pm 14 \mathrm{~g} ; P<0 \cdot 05$ versus control rats) and at the $14^{\text {th }}$ day, BDNF-treated animals weighed 29\% less than control rats $(301 \pm 21$ versus $424 \pm 15 \mathrm{~g} ; P<0 \cdot 01$ versus control rats). Figure 4 shows variations in SRIH mRNA signals in the PeVN of controls and treated animals. Quantification of SRIH mRNA levels (Fig. 5A) and the number of positive cells/section (Fig. 5B) showed this treatment decreased SRIH mRNA steady state levels $\left(\mathrm{F}_{1,8}=54 \cdot 6 ; P<0 \cdot 0001\right)$ by $14 \%(P<0 \cdot 01$ versus control rats; Fig. 5A) and the number of SRIH mRNA labeled neurons/section $\left(\mathrm{F}_{1,8}=15 \cdot 2 ; P<0 \cdot 0046\right)$ by $24 \%(P<0 \cdot 01$ versus control rats; Fig. $5 \mathrm{~B})$. In contrast, the SRIH content was significantly increased $\left(\mathrm{F}_{2,10}=4 \cdot 47 ; P<0 \cdot 041\right)$ by $47 \%$ after BDNF treatment $(63 \cdot 8 \pm 6 \cdot 6 \mathrm{ng} /$ hypothalamus versus $43.5 \pm 6.3 \mathrm{ng} /$ hypothalamus in control rats; $P<0 \cdot 05$ ) (Fig. 5C).

No differences in mRNA level and in SRIH content were observed between control and sham groups, and hybridizations with the sense probes did not reveal any positive signal.

\section{Discussion}

The major finding of this work is the evidence of an in vivo regulation of hypothalamic SRIH neurons after 

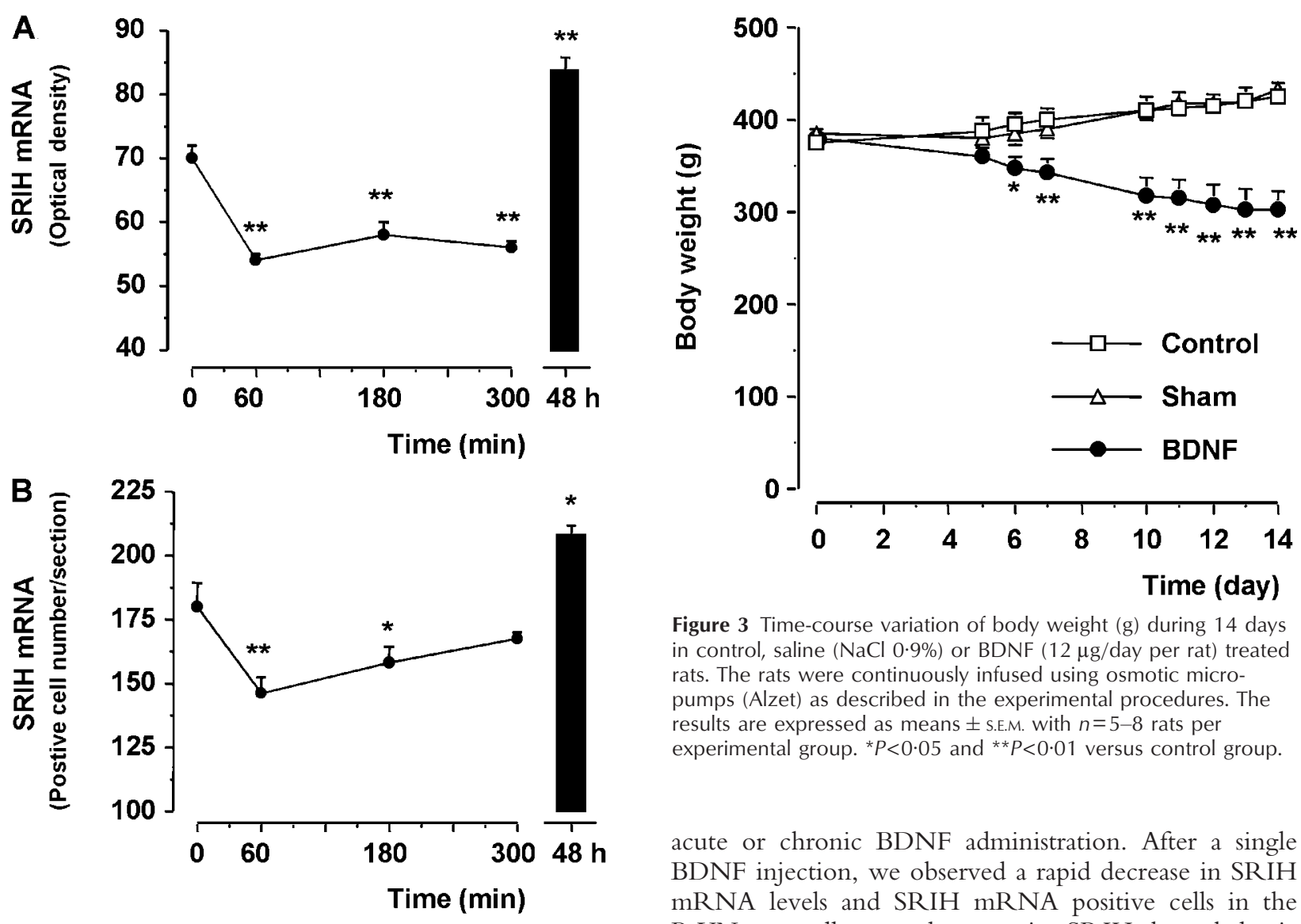

Figure 3 Time-course variation of body weight (g) during 14 days in control, saline ( $\mathrm{NaCl} 0.9 \%)$ or BDNF $(12 \mu \mathrm{g} /$ day per rat) treated rats. The rats were continuously infused using osmotic micropumps (Alzet) as described in the experimental procedures. The results are expressed as means \pm S.E.M. with $n=5-8$ rats per experimental group. ${ }^{*} P<0 \cdot 05$ and ${ }^{* *} P<0 \cdot 01$ versus control group.

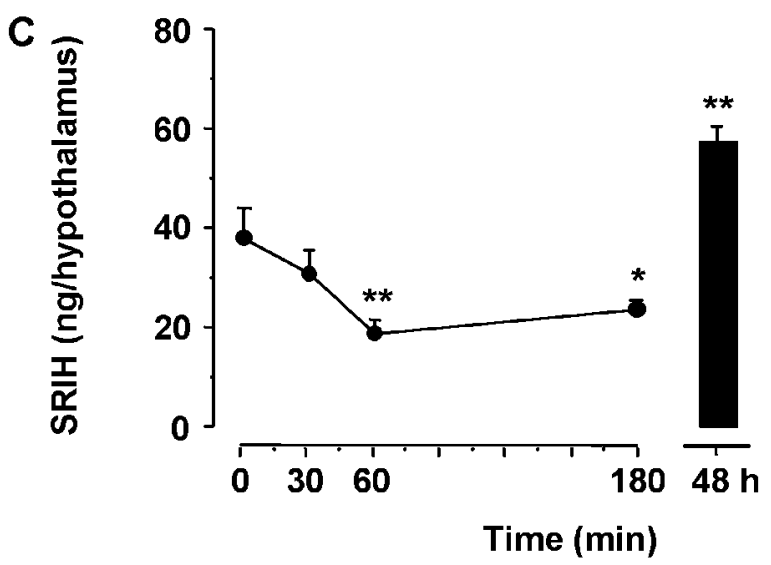

Figure 2 Effects of single i.c.v. BDNF injection ( $5 \mu \mathrm{g} / \mathrm{rat}$ ) on hypothalamic SRIH. (A) and (B) represent the optical density (OD) variations of the SRIH mRNA signal and the positive cells number/section respectively, for the SRIH mRNA signal in the PeVN in control adult male rats $\left(\mathrm{t}_{0}\right), 60,180,300 \mathrm{~min}$ and $48 \mathrm{~h}$ after the i.c.v. injection of BDNF. The results are expressed as means \pm S.E.M. of the percent of control (considered as $100 \%$ ), with $n=5-6$ rats per experimental group. ${ }^{*} P<0.05$ and ${ }^{* *} P<0 \cdot 01$ vs. control group. $(C)$ represents the time-course profiles of hypothalamic SRIH content in control rats $\left(\mathrm{t}_{0}\right)$ and 30, 60, $180 \mathrm{~min}$ and $48 \mathrm{~h}$ after a single i.c.v. injection of BDNF. The results are expressed as means \pm S.E.M. with $n=5-6$ rats per experimental group. ${ }^{*} P<0 \cdot 05$ and ${ }^{* *} P<0 \cdot 01$ versus basal value at $\mathrm{t}_{0}$.

acute or chronic BDNF administration. After a single BDNF injection, we observed a rapid decrease in SRIH mRNA levels and SRIH mRNA positive cells in the PeVN as well as a decrease in SRIH hypothalamic content. In contrast, $48 \mathrm{~h}$ later BDNF exerted a stimulatory effect on all of these parameters. These late effects are in line with our previous data showing a BDNF stimulatory effect on SRIH synthesis in cultured hypothalamic neurons after a $48 \mathrm{~h}$ treatment (Rage et al. 1999).

Among all of the SRIH synthesizing hypothalamic nuclei, the PeVN largely contains the highest number of hypothalamic SRIH perikarya (Alpert et al. 1976) and the highest amounts of brain SRIH are found in the median eminence, which result from the PeVN synthesizing activity (Brownstein et al. 1975). Therefore, and in accordance with other authors (Critchlow et al. 1981, Kiyama \& Emson 1990), it is reasonable to consider that a variation in SRIH hypothalamus content is a good functional reflect of SRIH synthesizing activity occurring in PeVN. Thus, a decreased SRIH content could be associated with a rapid stimulatory effect of BDNF on SRIH release, in accordance with our previous in vitro data (Marmigere et al. 2001).

Considering the high BDNF levels in the adult hypothalamus (Katoh-Semba et al. 1997, Rage et al. 2002) and the high expression of its mRNA and of its receptor in the PeVN (Marmigère et al. 1998), our present results provide solid evidence that BDNF has a physiological role in this structure. Moreover, we have reported high levels 


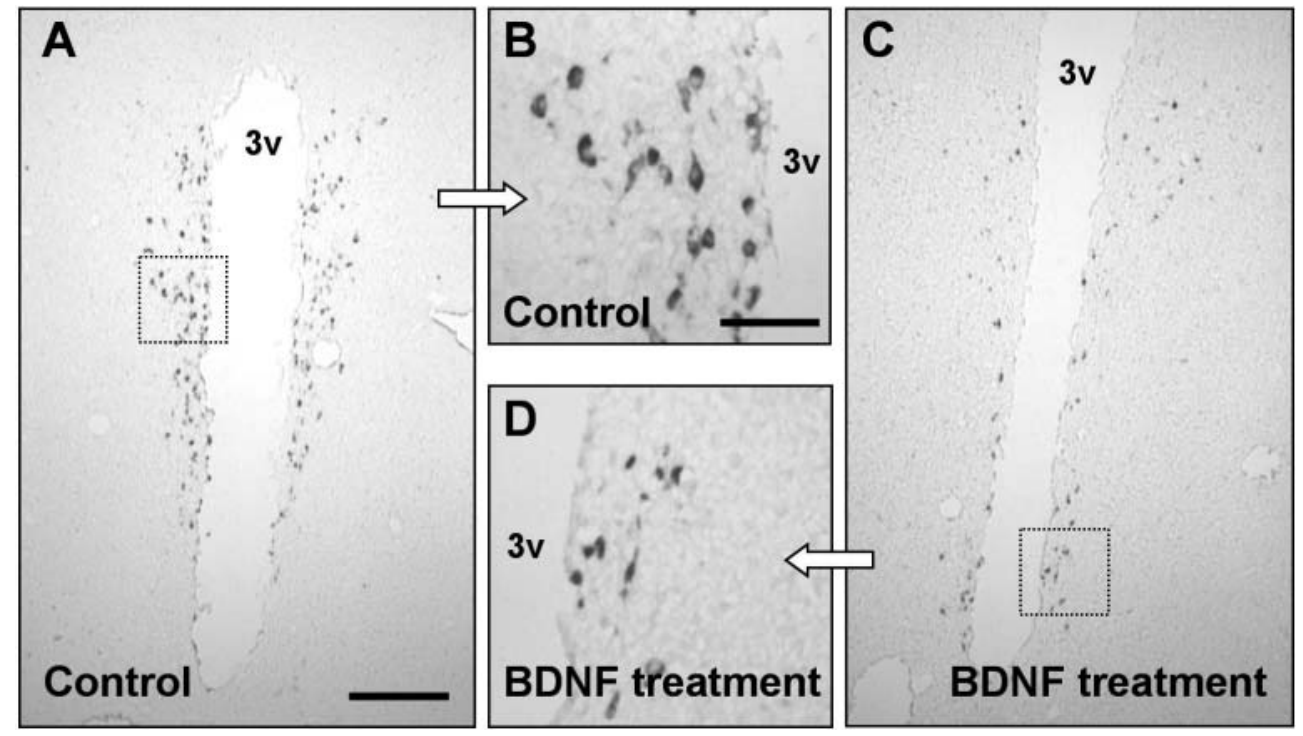

Figure 4 Effects of continuous BDNF administration ( $12 \mu \mathrm{g}$ /day per rat for 14 days) on hypothalamic SRIH mRNA expression in the PeVN, detected by in situ hybridization. Hypothalamic sections (10 $\mu \mathrm{m})$ were hybridized with digoxigenin-labeled SRIH oligonucleotide probe in control adult male rats (A and B) and in rats 14 days after continuous i.c.v. BDNF administration ( $\mathrm{C}$ and $\mathrm{D})$. Figures show representative photomicrographs of the PeVN sections hybridized with the SRIH probe. Photomicrographs A and C: Scale bar $=300 \mu \mathrm{m}$ and photomicrographs B and C: Scale bar $=80 \mu \mathrm{m}$. 3v: third ventricle.

of TrkB mRNA in the hypothalamus (Tapia-Arancibia et al. 2001) and demonstrated, by double immunocytochemical staining experiments, that $\mathrm{TrkB}$ receptors are located on somatostatinergic neurons (Rage et al. 1999). As a whole, we can infer that the effect reported here is probably direct, exerted by BDNF on these neurons in an autocrine or paracrine fashion. However, we cannot rule out the potential role of other endogenous neurotransmitters released after BDNF administration.

Nawa et al. (1994) reported that in vivo administration of BDNF in newborn rat brain increased the contents of several peptides including SRIH in brain cortex, striatum and hippocampus. These authors showed that intraventricular injection of BDNF linearly increased SRIH mRNA expression in the anterior neocortex, reaching maximal levels at $48 \mathrm{~h}$. Nevertheless, these authors failed to detect any marked influence of BDNF on SRIH or neuropeptide $\mathrm{Y}$ in the hypothalamus. The differences relative to our results could be explained by the fact that at neonatal stages, endogenous neurotrophin levels are sufficient to ensure peptidergic expression and exogenous administration of BDNF would therefore not further alter the peptide phenotype.

The second paradigm used here, i.e. long-term i.c.v. BDNF administration reproduced the stimulatory effect of BDNF on SRIH content described here (48 h after the single BDNF injection) and those described in previous in vitro studies (Rage et al. 1999, Loudes et al. 2000). Using this paradigm, contrary to the findings after the acute injection, no temporal correlation between changes in PeVN mRNA levels and peptide hypothalamic contents were observed. These data suggest that long-term BDNF administration strongly activate SRIH translation process which is probably associated to changes in the messenger turnover. Long continuous infusion of BDNF could also lead to modifications in the chemical environment and thereby induce structural rearrangements of the target brain regions investigated. Indeed, the balance between excitatory and inhibitory neurotransmission (TapiaArancibia et al. 2004) can be modified by a long-lasting exposure to BDNF. For instance, some neuropeptides can be hypersecreted as a consequence of the food intake decrease. That could be the case of vasoactive intestinal peptide (VIP) since on the one hand, it is involved in the food intake regulation (Tachibana et al. 2003) and on the other hand, it could be stimulated by BDNF (Villuendas et al. 2001) resulting in increased SRIH secretion (TapiaArancibia \& Reichlin 1985, De Los Frailes et al. 1991, Villuendas et al. 2001).

The BDNF induced-body weight loss observed here has been notably explained by a decrease in food intake (Pelleymounter et al. 1995, Siuciak et al. 1996). Among several other neuropeptides proposed (Wisse et al. 2003), hypothalamic SRIH (Feifel \& Vaccarino 1994, Scacchi et al. 2003) and VIP (Tachibana et al. 2003) could also be involved in the weight loss given their roles in food intake regulation. In anorexic humans, a low somatostatinergic tone has been related to the weight loss (Stoving et al. 2002). 

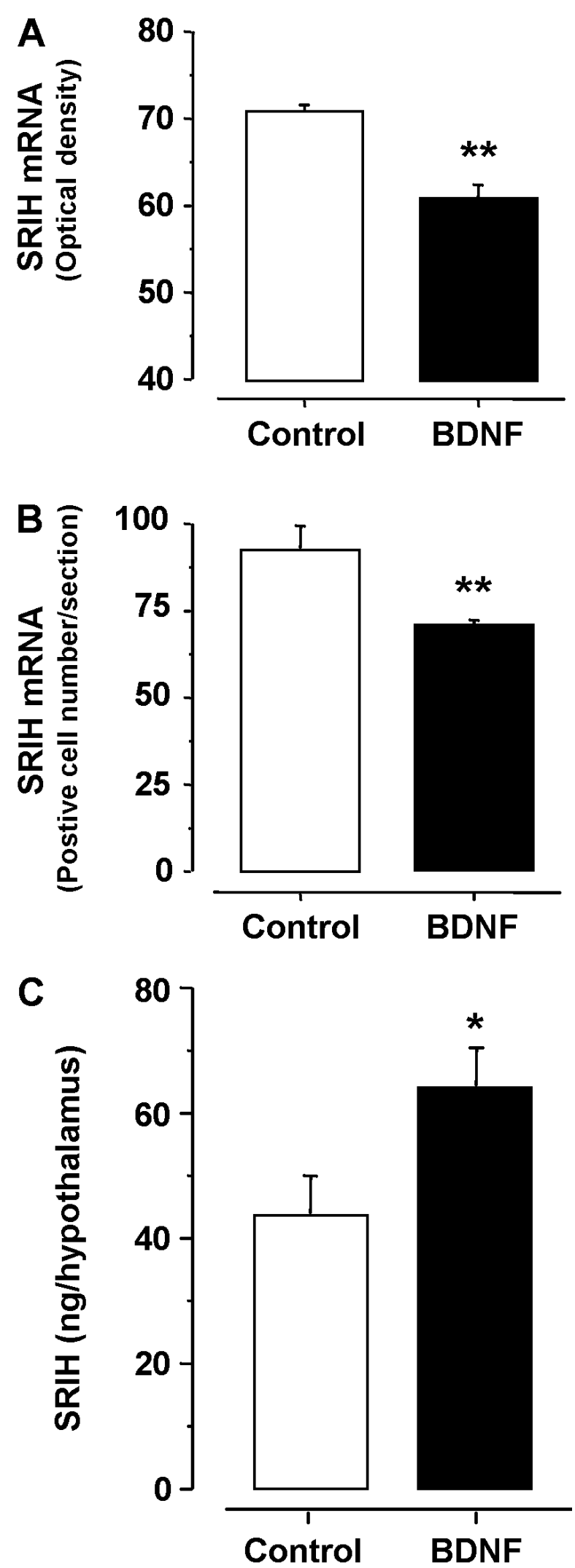

www.endocrinology-journals.org
Besides, BDNF i.c.v. administration induces an increase in corticotropin releasing hormone $(\mathrm{CRH})$ content and CRH mRNA level in the PVN (Givalois et al. 2004). $\mathrm{CRH}$ is known as a potent anorexigenic agent (Kalra et al. 1999). Since interactions between SRIH and CRH have been described (Aguila \& McCann 1985, Spada et al. 1990, Hisano \& Daikoku 1991), the BDNF/SRIH interaction could be exerted via CRH-mediation. Finally, we have also observed that long-term BDNF administration increases daily locomotor activity and temperature rhythms (Naert et al. unpublished observation). All of these actions may contribute to explain the weight loss measured in chronic BDNF-treated rats.

BDNF activation of TrkB receptors involves multiple second-messenger pathways that may underlie the described effects. It has been reported that cAMP responsive element binding (CREB) protein is a major mediator of neuronal neurotrophin responses (Finkbeiner et al. 1997). On the other hand, we previously showed that cAMP increased SRIH biosynthesis in experiments conducted with rat hypothalamic neurons or in NIH-3T3 fibroblast cells transfected with the rat SRIH gene (Montminy et al. 1986). Within the SRIH gene, a cAMP-responsive element has also been detected (Montminy et al. 1986). CREB is probably one signaling pathway by which BDNF activates SRIH gene expression in hypothalamic neurons.

In summary, our results show for the first time an in vivo regulation of SRIH hypothalamic neurons by BDNF in adult normal rats, which extend and confirm our previous in vitro data. Apart from a regulatory role in the food intake process above discussed, another physiological role of the BDNF/SRIH interaction might be found in the stress regulation. Indeed, as SRIH is massively released in the portal blood following application of different stressors, BDNF could contribute to the reconstitution of intracellular SRIH stocks once they have been exhausted by the strong stress demand.

\section{Acknowledgements}

This work was supported by the CNRS (France) and by grants from NARSAD (Independent Investigator Award 2002, USA) to LG, from Fondation Cino del Duca to S A

Figure 5 Effects of continuous BDNF infusion $(12 \mu \mathrm{g} /$ day per rat for 14 days) on hypothalamic SRIH. (A) illustrates the mean optical density (OD) and (B) the mean positive cell number/section of the SRIH mRNA signal in the PeVN of control and BDNF-treated rats. The results are expressed as means \pm S.E.M. of the percent of control (considered as $100 \%$ ), with $n=4-5$ rats per experimental group. ${ }^{*} P<0 \cdot 01$ versus control group. (C) shows hypothalamic SRIH contents in control and BDNF-treated rats. The results are expressed as means \pm S.E.M. with $n=5-8$ rats per experimental group. ${ }^{*} P<0.05$ versus control group. 
and from MENRT (France) to G N. The authors thank Regeneron Pharmaceuticals Inc. (USA) for the supply of BDNF and Mr E Savary for technical assistance. The authors declare that there is no conflict of interest that would prejudice the impartiality of this scientific work.

\section{References}

Aguila MC \& McCann SM 1985 The influence of hGRF, CRF, TRH and LHRH on SRIF release from median eminence fragments. Brain Research 348 180-182.

Alpert LC, Brawer JR, Patel YC \& Reichlin S 1976 Somatostatinergic neurons in andersom hypothalamus: immunohistochemical localization. Endocrinology 98 255-258.

Anderson KD, Alderson RF, Altar CA, DiStefano PS, Corcoran TL, Lindsay RM \& Wiegand SJ 1995 Differential distribution of exogenous BDNF, NGF, and NT-3 in the brain corresponds to the relative abundance and distribution of high-affinity and low-affinity neurotrophin receptors. Journal of Comparative Neurology 357 296-317.

Arancibia S, Payet O, Givalois L \& Tapia-Arancibia L 2001 Acute stress and dexamethasone rapidly increase hippocampal somatostatin synthesis and release from the dentate gyrus hilus. Hippocampus 11 469-477.

Benyassi A, Gavaldà A, Armario A \& Arancibia S 1993a Role of somatostatin in the acute immobilization stress-induced GH decrease in rat. Life Sciences 52 361-370.

Benyassi A, Roussel JP, Rougeot C, Gavalda A, Astier H \& Arancibia S 1993 b Chronic stress affects in vivo hypothalamic somatostatin release but not in vitro $\mathrm{GH}$ responsiveness to somatostatin in rats. Neuroscience Letters 159 166-170.

Brownstein MJ, Arimura A, Sato H, Schally AV \& Kizer JS 1975 The regional distribution of somatostatin in the rat brain. Endocrinology $961456-1461$.

Callahan WJ, Narhi LO, Kosky AA \& Treuheit MJ 2001 Sodium chloride enhances the storage and conformational stability of BDNF and PEG-BDNF. Pharmacology Research 18 261-266.

Critchlow V, Abe K, Urman S \& Vale W 1981 Effect of lesions in the periventricular nucleus of the preoptic-anterior hypothalamus on growth hormone and thyrotropin secretion and brain somatostatin. Brain Research 222 267-276.

De Los Frailes MT, Sanchez-Franco F, Lorenzo MJ, Tolon R, Lara J \& Cacicedo L 1991 Endogenous VIP regulates somatostatin secretion by cultured fetal rat cerebral cortical and hypothalamic cells. Regulatory Peptides 34 261-274.

Feifel D \& Vaccarino FJ 1994 Growth hormone-regulatory peptides (GHRH and somatostatin) and feeding: a model for the integration of central and peripheral function. Neuroscience Biobehavioral Reviews 18 421-433.

Finkbeiner S, Tavazoie SF, Maloratsky A, Jacobs KM, Harris KM \& Greenberg ME 1997 CREB: a major mediator of neuronal neurotrophin responses. Neuron 19 1031-1047.

Givalois L, Naert G, Rage F, Ixart G, Arancibia S \& Tapia-Arancibia L 2004 A single brain-derived neurotrophic factor injection modifies hypothalamo-pituitary-adrenocortical axis activity in adult male rats. Molecular and Cellular Neuroscience 27 280-295.

Große G, Djalali S, Deng DR, Höltje M, Hinz B, Schwartskopff K, Cygnon M, Rothe T, Stroh T, Hellweg R et al. 2005 Area-specific effects of brain-derived neurotrophic factor (BDNF) genetic ablation on various neuronal subtypes of the mouse brain. Developmental Brain Research 156 111-126.

Hisano S \& Daikoku S 1991 Existence of mutual synaptic relations between corticotropin-releasing factor-containing and somatostatin-containing neurons in the rat hypothalamus. Brain Research 545 265-275.

Kalra SP, Dube MG, Pu S, Xu B, Horvath TL \& Kalra PS 1999 Interacting appetite-regulating pathways in the hypothalamic regulation of body weight. Endocrine Reviews 20 68-100.

Katoh-Semba R, Takeuchi IK, Semba R \& Kato K 1997 Distribution of brain-derived neurotrophic factor in rats and its changes with development in the brain. Journal of Neurochemistry 69 34-42.

Kiyama H \& Emson PC 1990 Distribution of somatostatin mRNA in the rat nervous system as visualized by a novel non-radioactive in situ hybridization histochemistry procedure. Neuroscience 38 223-244.

Lapchak PA \& Hefti F 1992 BDNF and NGF treatment in lesioned rats: effects on cholinergic function and weight gain. Neuroreport 3 405-408.

Loudes C, Petit F, Kordon C \& Faivre-Bauman A 1999 Distinct populations of hypothalamic dopaminergic neurons exhibit differential responses to brain-derived neurotrophic factor (BDNF) and neurotrophin-3 (NT3). European Journal of Neuroscience 11 617-624.

Loudes C, Petit F, Kordon C \& Faivre-Bauman A 2000 Brain-derived neurotrophic factor but not neurotrophin-3 enhances differentiation of somatostatin neurons in hypothalamic cultures. Neuroendocrinology 72 144-153.

Makara GB, Palkovits M, Antoni FA \& Kiss JZ 1983 Topography of the somatostatin-immunoreactive fibers to the stalk-median eminence of the rat. Neuroendocrinology 37 1-8.

Marmigère F, Rage F, Tapia-Arancibia L \& Arancibia S 1998 Expression of mRNAs encoding BDNF and its receptors in adult rat hypothalamus. Neuroreport 9 1159-1163.

Marmigère F, Choby C, Rage F, Richard S \& Tapia-Arancibia L 2001 Rapid stimulatory effects of brain-derived neurotrophic factor and neurotrophin- 3 on somatostatin release and intracellular calcium rise in primary hypothalamic cell cultures. Neuroendocrinology 74 43-54.

Mizuno K, Carnahan J \& Nawa H 1994 Brain-derived neurotrophic factor promotes differentiation of striatal GABAergic neurons. Developmental Biology 165 243-256.

Montminy MR, Low MJ, Tapia-Arancibia L, Reichlin S, Mandel G \& Goodman RH 1986 Cyclic AMP regulates somatostatin mRNA accumulation in primary diencephalic cultures and in transfected fibroblast cells. Journal of Neuroscience 6 1171-1176.

Nawa H, Bessho Y, Carnahan J, Nakanishi S \& Mizuno K 1993 Regulation of neuropeptide expression in cultured cerebral cortical neurons by brain-derived neurotrophic factor. Journal of Neurochemistry 60 772-775.

Nawa H, Pelleymounter MA \& Carnahan J 1994 Intraventricular administration of BDNF increases neuropeptide expression in newborn rat brain. Journal of Neuroscience 14 3751-3765.

Paxinos G \& Watson C 1997 The rat brain in stereotaxic coordinates, edn 3. Eds G Paxinos \& C Watson. San Diego, CA, USA: Academic Press.

Pelleymounter MA, Cullen MJ \& Wellman CL 1995 Characteristics of BDNF-induced weight loss. Experimental Neurology 131 229-238.

Rage F, Riteau B, Alonso G \& Tapia-Arancibia L 1999 Brain-derived neurotrophic factor and neurotrophin-3 enhance somatostatin gene expression through a likely direct effect on hypothalamic somatostatin neurons. Endocrinology 140 909-916.

Rage F, Givalois L, Marmigère F, Tapia-Arancibia L \& Arancibia S 2002 Immobilization stress rapidly modulates BDNF mRNA expression in the hypothalamus of adult male rats. Neuroscience 112 309-318.

Scacchi M, Ida Pincelli A \& Cavagnini F 2003 Nutritional status in the neuroendocrine control of growth hormone secretion: the model of anorexia nervosa. Frontiers in Neuroendocrinology 2003 24 200-224. 
Siuciak JA, Boylan C, Fritsche M, Altar CA \& Lindsay RM 1996 BDNF increases monoaminergic activity in rat brain following intracerebroventricular or intraparenchymal administration. Brain Research 710 11-20.

Spada A, Reza-Elahi F, Lania A, Bassetti M \& Atti E 1990 Inhibition of basal and corticotropin-releasing hormone-stimulated adenylate cyclase activity and cytosolic CA2+ levels by somatostatin in human corticotropin-secreting pituitary adenomas. Journal of Clinical Endocrinology and Metabolism 70 1262-1268.

Stoving RK, Andersen M, Flyvbjerg A, Frystyk J, Hangaard J, Vinten J, Koldkjaer OG \& Hagen C 2002 Indirect evidence for decreased hypothalamic somatostatinergic tone in anorexia nervosa. Clinical Endocrinology 56 391-396.

Tachibana T, Saito S, Tomonaga S, Takagi T, Saito ES, Boswell T \& Furuse M 2003 Intracerebroventricular injection of vasoactive intestinal peptide and pituitary adenylate cyclase-activating polypeptide inhibits feeding in chicks. Neuroscience Letters $339203-206$

Tapia-Arancibia L \& Reichlin S 1985 Vasoactive intestinal peptide and PHI stimulate somatostatin release from rat cerebral cortical and diencephalic cells in dispersed cell culture. Brain Research 336 67-72.
Tapia-Arancibia L, Rage F, Givalois L, Dingeon P, Arancibia S \& Beauge F 2001 Effects of alcohol on brain-derived neurotrophic factor mRNA expression in discrete regions of the rat hippocampus and hypothalamus. Journal of Neuroscience Research 63 200-208.

Tapia-Arancibia L, Rage F, Givalois L \& Arancibia S 2004 Physiology of BDNF: focus on hypothalamic function. Frontiers in Neuroendocrinology 25 77-107.

Villuendas G, Sanchez-Franco F, Palacios N, Fernandez M \& Cacicedo L 2001 Involvement of VIP on BDNF-induced somatostatin gene expression in cultured fetal rat cerebral cortical cells. Molecular Brain Research 94 59-66.

Wisse BE, Schwartz MW \& Cummings DE 2003 Melanocortin signaling and anorexia in chronic diseases states. Annals of the New York Academy of Sciences 994 275-281.

Yan Q, Matheson C, Sun J, Radeke MJ, Feinstein SC \& Miller JA 1994 Distribution of intracerebral ventricularly administered neurotrophins in rat brain and its correlation with trk receptor expression. Experimental Neurology 127 23-36.

Received 8 December 2005

Accepted 12 December 2005 